\title{
Development Electronic Module On Subject Matter Kalor For Junior High School Student
}

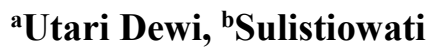 \\ ${ }^{a}$ Curriculum and Educational Technology Universitas Negeri Surabaya Surabaya, Indonesia \\ ${ }^{\mathrm{b}}$ Curriculum and Educational Technology Universitas Negeri Surabaya Surabaya, Indonesia \\ Corresponding e-mail utaridewi@unesa.ac.id
}

\begin{abstract}
-
This study aims to develop electronic module media viable and effective in science subjects and subject matter kalor for students of class VII G SMPN 34 Surabaya. The type of research used is research development. Model used is ADDIE Model with stages of Analysis, Design, Development, Implementation and Evaluation. Data collection techniques are interviews, questionnaires and tests. Based on the analysis that has been done, it can be deduced that the validation results media from media experts and subject matter experts are worthy of media used by the revision. The results of product testing questionnaire to students of class VII SMPN 34 Surabaya, it can be concluded that: (a) the results of individual testing percentage of $83.33 \%$ (excellent), (b) the results of a small group of test percentage $87 \%$ (excellent), (c) the results of field trials percentage of $88.15 \%$ (excellent). With these results, the media electronic module is fit for use. In addition to the results of the calculation of the ratio between pretest and posttest performed is greater than the $t$ table $4.94>2.02809$. This indicates that the electronics module in science subjects and subject matter kalor effectively to improve student learning outcomes.
\end{abstract}

Keywords-Development;Media;Electronic Module

\section{INTRODUCTION}

Science subjects are often defined by learners as difficult subjects, because the subjects of science require high memory. In this semester, SMPN 34 Surabaya has started implementing digital class, so all subjects have to use multimedia based technology. All students and teachers are required to use the laptop in every learning process. This is very supportive if learning using various media based on technology. The learning outcomes generated by students in the subject matter of heat and movement are also low. The textbook used can not explain Course material in detail. Textbook only mention the subject matter to be discussed. In addition, textbooks are also unable to explain directly about a process and experiments to be done by students. With this electronic module media activities learning will become more interesting and fun. Students will feel more challenged and will not quickly feel saturated because of the audio as well videos that will explain the material. Electronic module also can overcome the limitations of space and time in learning. Thus, students do not have to again imagine the abstract material, because the module electronics will make the material more concrete. In addition, with the existence of electronic modules, students will more able to learn independently. Every student can develop in accordance with the ability possessed. Students also not only act as objects passive, but they also play an active role in thinking and in teaching and learning activities.

\section{METHODS}

This research is a research that aims to produce a learning media in the form of electronic modules on the subject matter of heat and its changes, then the appropriate development model is a development research model. The development model used by researchers is the development model of ADDIE (Analyze, Design, Development, Implementation, Evaluation).

Data collection Techniques and research instrumen. Interview method for validation by material experts and media experts. The type of interview used in this research is semi interview structured. This interview data analysis technique is the basis for making revisions, suggestions and inserts from material experts and media experts. Questionnaire method for students' assessment of the media. In this research, developers use closed questionnaire with rating-scale form and questionnaire Open to provide suggestions and feedback. The questionnaire is used as the data collection instrument provided by the students to get input on the developed product. Teknik data collection in the form of tests used to measure the success of students and used to measure the success of the learning process do. 
Data analysis of electronic media module study by material experts and media experts, Analysis of the questionnaire results obtained from the responses in the form of questionnaire assessment of students. The data is described by percentage technique. Analysis of learning result test. Researchers want to see if there is a difference A significant learning outcomes of students before and after the use of electronic module media in the learning process.

\section{RESULT \& DISCUSSION}

Munadi (2013: 7) states that the media is everything that can deliver and deliver messages from the source in a planned manner so as to create a conducive learning environment where recipients can make the learning process efficiently and effectively. According to Adiputra (2014: 21) electronic module is a form of presentation of self-study materials systematically arranged into the smallest learning unit to achieve certain learning objectives, presented in electronic format.

Prior to the implementation of research or direct implementation of media into schools, there are several stages to be done according to the ADDIE development

model used. The stages are as follows:

\section{A. Analysis}

The initial stage is done by doing direct obeservasi to SMPN 34 Surabaya. Next is to identify the existing problems, then do the needs analysis and explore the potential that exist in SMPN 34 Surabaya. The analysis is based on the results of documentation and direct interviews with subject teachers.

\section{B. Design}

At the design stage, the activities undertaken are to formulate the material items together with the existing material experts. In addition, at this stage developers also create a flowchart and storyboard that will be used for Basis in developing electronic modules. In addition to preparing these matters, also the preparation of RPP (Learning Implementation Plan) as the basis for the implementation of media use in learning.

\section{Develoment}

- Production. At the production step, the developer has started making electronic module design using Adobe Flash Professional CS7 software. In addition to using the software, developers also use other supporting software such as Corel Draw CS5, Adobe Photoshop CS3, Adobe Premier, and Microsoft Word 2010.

- Media validation is used to correct or revise media that is less suitable to the characteristics of students, media characteristics, and characteristics of existing materials.
Validation is done by using questionnaires and interviews. The result of this media validation is an electronic module media worth using with revision. Revisions are made based on suggestions and inputs provided by preselected experts.

- Trial media is a process of applying media before diguanakan directly to students in learning activities in the classroom. These media trials were conducted twice, ie individual trials and small group trials. Result data of these trials will be used to test media feasibility in the learning process. Results from individual trials were $83.33 \%$ (very good), whereas the results from small group trials were $87 \%$ (very good). From both trials that have been done can be concluded that the electronic module media is very good and feasible to use.

- Validity and reliability of the item. Before conducting field tests to retrieve pretest and posttest data, the researcher to test the validity and reliability of the item in question first. This is done to find out which issues are valid and reliable to be a matter of pretest and posttest. The subject of validity and reliability test this item is a student of class VII I, with a total of 30 students. Validity of this problem using the formula point

\section{Implementation}

Data obtained from field trial results that have been done then dianalis. This is done to see the success of the learning system which has been done. To know the effectiveness level of existing electronic module is to compare pretest with existing posttest. Based on the calculation using t-test above, obtained tcount value of 4.94. Then consulted by using ttable with $5 \%$ significance level, then get d.b equal to $\mathrm{N}-1$ $=38-1=37$. ttable of d.b 37 is 2.02809 . The result is $t$ hitung $>\mathrm{t}$ table ie 4.94> 2.02809. This shows that the electronic module of the subject matter of the subject matter of heat and its movement is effective to improve student learning outcomes.

\section{E. Evaluation}

At this stage of evaluation there is no specific and detailed explanation. Because in the ADDIE development model, evaluation and revision can be done directly at each stage. It also applies to this development, any evaluation and revision being made and explained directly at each stage.

\section{CONCLUSION}

Judging from all the development process that has been done by the researcher, it can be concluded that: Based on media validation that has been done on media experts and material experts, it can be 
concluded that the electronic module media is feasible to use.

In addition, the trials that have been performed have the following results: (1) individual trials with percentage of $83.33 \%$; (2) small group trial with percentage of $87 \%$; (3) field trials with percentage of $88.15 \%$.

With the percentage is then it can be concluded that the electronic module media feasible to use. Based on the results of field trials, tcount is obtained greater than the $\mathrm{t}$ table is $4.94>2.02809$. Thus, it can be concluded that the module Electronic about the heat and its displacement for grade VII students SMPN 34 Surabaya effective in improving learning outcomes.

\section{ACKNOWLEDGMENT}

Our gratitude to those who have participated in this research. Acknowledgments to the head of the Department of Education and Curriculum Curriculum UNESA, Dra. Sulistiowati, M.Pd, principal and teacher and students of SMPN 34 Surabaya who have participated in this research.

\section{REFERENCES}

[1] Adiputa, I Nyoman Sudiartayasa. 2014. Development EModule on the Material "Perform Installation Network Operating System Based on GUI and Text " For Students of Class X Computer Engineering Network SMK Negeri 3 Singaraja. Set Articles of Engineering Education Students Informatics (KARMAPATI). Volume 3, Number 2. (On line).

(Http://pti.undiksha.ac.id/karmapati/vol3no1/3.pdf)

[2] Arikunto, Suharsimi. 2013. Research Procedure A Practice Approach. Jakarta: PT Rineka Cipta

[3] Asyhar, Rayandra. 2012. Creative Developing Media Learning. Jakarta: Reference Jakarta.

[4] BSE. 2014. Natural Science Master's Book. Jakarta: Ministry of Education and Culture.

[5] Hosnan. 2014. The Scientific and Contextual Approach In 21st Century learning. Bogor: Ghalia Indonesia.

[6] R. Nicole, Januszewski, Alan dan Molenda, Michael. 2008. Educational Technology: A Definition With Commentary. New York.

[7] Miarso, Yusufhadi. 1986. Definition of Technology Education / Definition and Terminology Task Force AECT. Jakarta: Rajawali.

[8] Munadi, Yudhi. 2013. Learning Media A New Approach. Jakarta: Reference (GP Press Group) 